\title{
Arteria vertebralis thrombosis egy 7 éves gyermekben
}

\author{
Viczei Alexandra dr. ${ }^{1}$ - Lapis István dr. ${ }^{1}$ \\ Brzózka Ádám Marián dr. ${ }^{2}$. Szeifert György dr. ${ }^{1,3}$
}

\author{
${ }^{1}$ Békés Megyei Központi Kórház, Pándy Kálmán Tagkórház, Idegsebészeti Osztály, Gyula \\ ${ }^{2}$ Szegedi Tudományegyetem, Általános Orvostudományi Kar, Szent-Györgyi Albert Klinikai Központ, \\ Radiológiai Klinika, Szeged \\ ${ }^{3}$ Semmelweis Egyetem, Általános Orvostudományi Kar, Idegsebészeti Tanszék, Budapest
}

\begin{abstract}
Az agyi érrendszer elzáródásos panaszai elsősorban felnőttkorban jelentkeznek, nem ritkák azonban gyermekek esetében sem. A gyermekkori stroke gyakorisága 2,5/1 000000 fó; ilyenkor általában az arteria carotis interna vagy az arteria cerebri media érintett. Az ischaemiás stroke-ok 25\%-a a hátsó keringési rendszer területén keletkezik. Az arteria vertebralis extracranialis szakaszának stenosisa 18\%-ban a jobb oldalon, 22,3\%-ban a bal oldalon észlelhető. Esetünkben egy 7 éves kisfiú kórtörténetét mutatjuk be, aki facialis paresis, súlyosbodó ataxia és somnolentia tüneteivel került egy megyei kórház gyermek intenzív osztályára. A készült kontrasztos koponya angiográfiás MR-vizsgálaton akut ischaemiás elváltozások voltak láthatók, valamint sejteni lehetett, hogy a bal oldali arteria vertebralis gracilisabb; a hypoplasia azonban csak a beteg egyetemi centrumba kerülése után, az ott elvégzett, a nyaki erekre is kiterjedő TOF - (time of flight) angiográfia és nyaki ultrahang készítését követően bizonyosodott be. A beállított gyógyszeres kezelések hatására az ischaemiát okozó artériás thrombus feloldódott, majd megkezdődött a rehabilitáció folyamata, melynek során a beteg állapota nagymértékben javult. A gyermek kórházba kerülése előtt hónapokkal észlelt, magatartás- és figyelembeli zavarainak romlása felveti a már korábban bekövetkező átmeneti ischaemiás periódusok lehetőségét is. A hátsó keringési rendszert érintő stroke-ok etiológiája változó, többször kerültek már leírásra különböző háttérrel. Esetünkben a fejlődési rendellenesség - 'bow hunter' szindróma tünik a legvalószínúbbnek. A készült dinamikus nyaki ultrahangvizsgálat is erre utaló eredményt adott. Időintervallumon belül szóba jöhet az arteria vertebralis thrombosis kezelése endovascularis módszerek segítségével is. Ennek kivitelezhetősége érdekében azonban fontos a mielőbbi pontos diagnózis felállítása a megfelelő képalkotó vizsgálatok segítségével és a betegnek a kezelésére felkészült centrumba juttatása. Orv Hetil. 2021; 162(47): 1902-1907.
\end{abstract}

Kulcsszavak: arteria vertebralis, 'bow hunter' szindróma, ischaemia

\section{Vertebral artery thrombosis in a 7 -year-old child}

Cerebrovascular obstruction primarily affects adults, but it is not uncommon in children either. The incidence of childhood stroke is $2.5 / 1000000$ population, usually affecting the internal carotid artery or the middle cerebral artery. The posterior circulatory system is involved in $25 \%$ of ischemic strokes. Stenosis of the extracranial section of the vertebral artery is demonstrated in $18 \%$ on the right side and $22.3 \%$ on the left side. We present the case history of a 7-year-old boy who was admitted to the pediatric intensive care unit of a county hospital with symptoms of facial palsy, progrediating ataxia and somnolence. Contrast-enhanced angiographic MR images of the skull revealed acute ischemic lesions and suggested stenosis of the left vertebral artery, then it was confirmed by TOF (time of flight) angiography of vessels of the neck and cervical ultrasound examination. The arterial thrombus causing ischaemia was eliminated by drug treatment and the rehabilitation process could be started. The patient's condition improved considerably following that. Deterioration in behavioral and attentional problems of the patient, which had been realised months prior to hospitalisation, raises the possibility of earlier ischemic periods. The etiology of strokes affecting the posterior circulatory system has been described with different backgrounds. In the presented case, a developmental disorder - bow hunter's syndrome seems to be the most likely one. The result of dynamic cervical ultrasound examination also supported this theory. Treatment of vertebral artery thrombosis with endovascular methods may also be considered within a time interval. However, to make it feasible, it is important to establish an accurate diagnosis as soon as possible by appropriate imaging studies, and to transfer the patient to a specialised center.

Keywords: vertebral artery, bow hunter's syndrome, ischemia

Viczei A, Lapis I, Brzózka ÁM, Szeifert Gy. [Vertebral artery thrombosis in a 7-year-old child.] Orv Hetil. 2021; 162(47): 1902-1907.

(Beérkezett: 2021. április 9.; elfogadva: 2021. május 4.) 


\section{Rövidítések}

$\mathrm{APC}=$ aktivált protein $\mathrm{C} ; \mathrm{DSA}=$ digitális szubtrakciós angiográfia; DWI = (diffusion-weighted imaging) diffúziósúlyozott képalkotás; EEG = elektroencefalográfia; LMWH = (lowmolecular-weight heparin) kis molekulatömegú heparin; $\mathrm{MR}$ = mágneses rezonancia; OMSZ = Országos Mentőszolgálat; $\mathrm{PEG}=$ percutan endoszkópos gastrostomia; $\mathrm{TOF}=($ time of flight) repülési idó

Az arteria (a.) vertebralis elzáródásának jelei a kialakult ischaemia helyétől, valamint az elzáródás típusától függően, többféleképpen jelentkezhetnek. Kezdeti tünet gyakran a szédülés, hányás, fej- vagy nyaki fájdalom. Egyéb gyakori tünet a gyengeség, ataxia, diplopia, beszédzavarok és a mentális állapot megváltozása [1]. A vertebrobasilaris rendszer thrombosisát a betegek felében átmeneti ischaemiás rohamok előzik meg az elzáródás előtti napokban vagy hetekben. Az embolicus események azonban hirtelen és drámai tüneteket okoznak prodroma nélkül, melyek felnőttek esetében gyakran súlyos következményekkel társulnak. A gyermekeket érintő betegségek kimeneteléről azonban még keveset tudunk [2].

Gyermekkorban az akut ischaemiás stroke megjelenése jóval ritkább, mint felnőttkorban. Incidencája 2-13/100 000 beteg/év az 1 hónapnál idősebb és 18 évnél fiatalabb korcsoportot tekintve. A leggyakrabban 1-5 éves korban fordul elő, fiúkban többször észlelhető. A stroke incidenciája újszülöttek (25-40/100 000) és koraszülöttek (100/100 000) esetében ennél magasabb arányt is elérhet [3].

Időskorban az atherosclerosis nagy fokban hozzájárulhat az a. vertebralis elzáródásához, gyermekkorban azonban gyakoribb a szív- és érrendszeri eredetû embolia előfordulása [4]. Az amúgy egészséges gyermeknél kialakuló akut stroke fertőző etiológiát vet fel, a leggyakrabban tuberculosis, meningitis, encephalitis áll a hátterében. Veleszületett érfejlődési rendellenesség a lakosság körülbelül 10\%-ánál észlelhető, ezek a betegek azonban általában jól kompenzálnak. A nyaki a. carotis és az a. vertebralis dissectiója fiatalok körében a stroke egyik jól ismert oka. Elöfordulhat az a. vertebralis primer occlusiós betegsége is, amely a veleszületetten kanyargós eret a CII. szintnél érinti [5]. A CI-CII. szegmens mechanikai sérülése, trauma, nyaki gerinc manipulációja során atlantoaxialis instabilitás alakulhat ki, mely a krónikus subluxatio következtében az a. vertebralis elzáródását okozhatja [6]. Leírásra került az a. vertebralis rotációs elzáródása, az úgynevezett 'bow hunter' szindróma. Ennek oka az a. vertebralis csontos vagy szalagos struktúrákhoz való nyomódása, például a CI. csigolya rendellenessége: a ponticulus posticus - Kimmerle-anomália (a ligamentum atlantooccipitale posterius elcsontosodása) esetén [7]. Ebben az esetben fejfordítás során az egyik oldali a. vertebralis kompressziója jön létre, jellemzően az atlantoaxialis ízület szintjén. Maga a kórforma ritkaságnak számít, 2012-ig körülbelül 40 rotációs a. vertebralis szindrómás esetet mutattak be. Felnőtteknél a jól ismert tünetcsoportot, a nyaki rotációs vertigót okozhatja [8], ez azonban gyermekekben igen ritka és nehezen kimutatható kórkép, melyről a hazai irodalomban még nem született publikáció. A polycytaemia vera myeloproliferativ betegség, mely a fokozott vérviszkozitás miatt szintén hozzájárulhat thromboemboliás folyamatok kialakulásához [9]. Az a. vertebralis elzáródásának leggyakoribb helye az atlas ívének és az a. vertebralisnak a találkozása közötti terület [10].

\section{Esetismertetés}

Facialis paresis gyanúja és zavart tudatállapot miatt szállította az OMSZ a 7 éves fiúgyermeket kórházunk gyermek intenzív részlegére. Szülei elmondása szerint gyermekük az éjszakát nyugtalanul töltötte, sokat forgolódott. Reggel homályos látásra kezdett panaszkodni, majd a gyermek bal szeme kifelé fordult. Ezt követően járása fokozatosan romlott, beszéde elkentté vált. A gyermek már egy hónapja panaszkodott fejfájásra, valamint homályos látásra is, ezért szemésznél jártak, aki statusában eltérést nem talált.

Érkezéskor a gyermek éber, térben és időben orientált, de viselkedése inadekvát, nyugtalan, néha somnolens. Utasításokat végrehajt, beszéde elkent, igen nehezen érthető. Vérgáz- és laborértékeiben enyhén emelkedett laktátszint észlelhető. Infekcióra utaló jel nincs. Szíve felett 2/6-os systolés zörej hallható, egyebekben belszervi statusa korának megfelelő. Szemészeti konzílium szerint a bal pupilla tágabb, és fényre is kevésbé reagál, mint a jobb oldali. Fundusvizsgálat során a bal oldalon határozottan halványabb látóidegfó észlelhető. Szemész kolléga a nervus opticust is érintő térfoglaló folyamat gyanúját vetette fel.

Neurológiai vizsgálat során a Kernig-tünet jelzetten pozitív. A bal oldali bulbus temporalis irányba fixált, konjugált szemmozgás nincs. Anisocoriás pupillák. Bal oldalon minimálisan szúkebb szemrés, a bal szájzug elhúzódva. A gyermek a fejét gyakran jobbra billenti. A jobb végtagoknál zászlótünet, a felső végtagoknál pronációs tendencia jelentkezik. A jobb oldalon spontán Babinski-reflex észlelhető. Ataxia miatt Romberg-helyzetbe nem hozható, célkísérleteknél egyértelmú jobb oldali felső végtagi ataxia látható. A beteg viselkedésében változó aktivitású fokozott mozgási kényszer, mely anyai hangra csillapodik. Beszéd helyett már csak zümmögésszerü hangot hallat, kérdésekre azonban fejbólintással válaszol. Az EEG-vizsgálat bal oldali túlsúlyú globális funkciózavart jelzett.

Sürgős strukturális agyi MR- és kontrasztos MRangiográfiás vizsgálat készült, amely a bal oldalon cerebellarisan parasagittalisan (1. ábra) és a törzsdúcokban akut ischaemiának megfelelő DWI-jel-intenzív területeket ábrázolt, a hippocampalis területeken girlandszerü halmozással (2. ábra). Ez a halmozás virális eredetű 
encephalitisre utalhat, de ezt a mikrobiológiai vizsgálatok kizárták. Másik oka a már korábban ischaemiás károsodást szenvedő agyterületek reperfúziója után fellépő meningealis, reaktív halmozás lehet. Az angiográfiás képeken a bal a. vertebralis gracilisabbnak tünt (3. ábra).

Az idegsebészeti konzílium a bal cerebellumban keringési zavart véleményezett, esetleges vénás malformáció lehetőségét vetette fel.

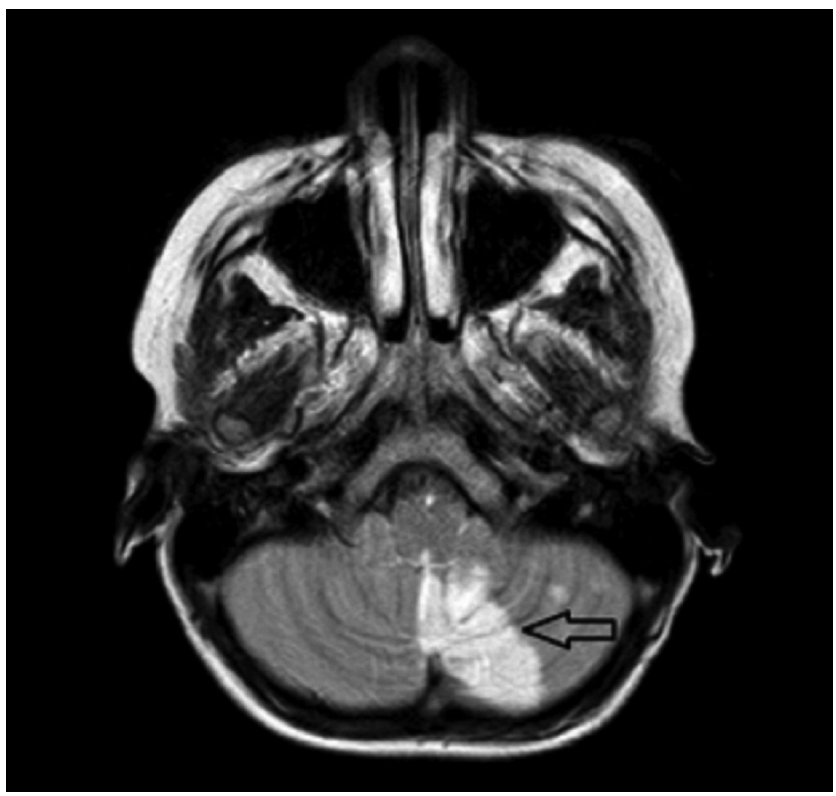

1. ábra

MR-felvétel. Bal oldalon cerebellarisan ischaemiás, DWI-jel-intenzív terület (nyíl)

DWI = diffúziósúlyozott képalkotás; $\mathrm{MR}=$ mágneses rezonancia

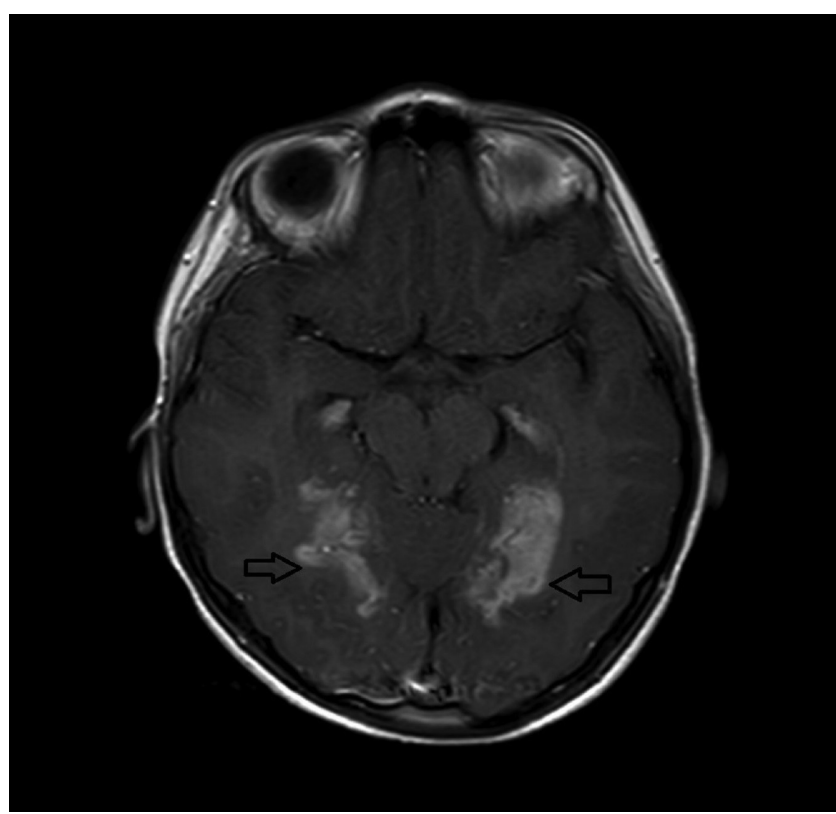

2. ábra

MR-felvétel. A hippocampalis területeken girlandszerű kontrasztanyag-halmozás (nyíl)

$\mathrm{MR}=$ mágneses rezonancia
A gyermek állapotában fokozatos progressziót észleltek; a képalkotó vizsgálatok elvégzése közben csámcsogó mozgás jelent meg, a beteg olykor kifejezetten nyugtalanná, majd somnolenssé vált, bradycard tendencia lépett fel, és erôs fejfájásra panaszkodott. Fájdalomcsillapító és re-, valamint dehidráló kezelésben részesült. Sürgősséggel ugyanezen nap délutánján OMSZ segítségével intubálva, lélegeztetve stabil, de súlyos általános állapotban további gyógykezelés céljából egyetemi klinika gyermek intenzív részlegére szállíttatták át.

A gyermekklinikán nyaki ultrahangvizsgálat készült, mely a bal a. vertebralis Vl-szakaszán peckelő, kis volumenú, praeocclusiv áramlást mutatott, V2-szakaszában azonban áramlást nem tudott kimutatni, ami a két érszakasz közötti thrombus jelenlétére utalt. Érsebészeti konzílium alapján, tekintettel a tünetek megjelenése óta eltelt időre, intravénás thrombolysis, valamint thrombectomia már nem volt indikálható. Átvétele napján extubálták, majd anti-Xa-szint-ellenőrzés mellett antikoaguláns (LMWH-) terápiát és acetilszalicilsavat indítottak. Laboratóriumi vizsgálatok történtek autoimmun betegségek irányában, negatív eredménnyel. Liquor- és hemokultúra-tenyésztések kórokozót nem mutattak ki. A laboreredményekben infekcióra utaló eltérés nem volt. A kardiológiai szakvizsgálat kóros eltérést nem talált. Nyelészavar, valamint per os táplálhatatlanság miatt PEG beültetése történt. Az MR-felvételek elemzése során az artériákat érintő komplex fejlődési variációt találtak. A bal a. carotis communis a truncus brachicephalicusból ered (bovine arch), a bal oldali gracilisabb a. vertebralis pedig közvetlenül az aortából (4. ábra). Bal oldalon fetalis a. cerebri posterior látható gracilis P1 - és P2-szakaszokkal, erős a. communicans posteriorral, míg a jobb oldali a. communicans gracilisebb. Az a. basilaris oszlásánál, a mesencephalicus perforans ágak és a thalamo-subthalamicus artériák eredésénél 1-2 mm-es jelkiesés látható, mely thrombus lehet (5. ábra), továbbá az érágak által ellátott régiókban ischaemiás eltérések azonosíthatók. A kontroll koponya-MR-vizsgálat akut-szubakut stroke jeleit igazolta (6. ábra). A felvételeken látható bal oldali friss és mindkét oldali régebbi posterior stroke-ok jelenléte periodikus, multiplex embolisatio lehetőségét

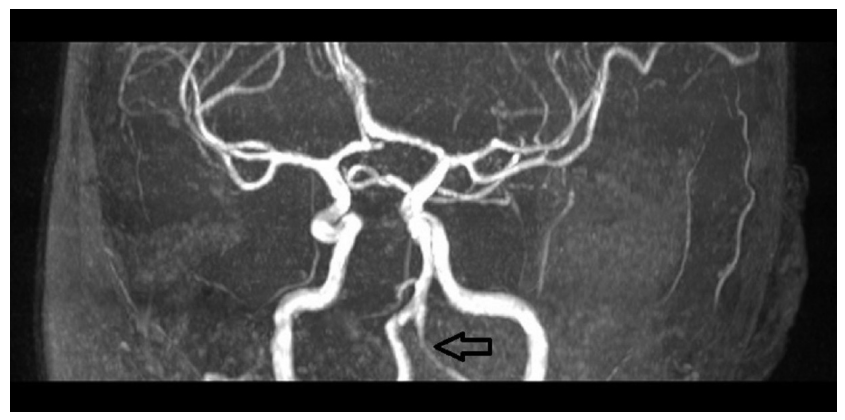

3. ábra Kontrasztos MR-angiográfiás felvétel. Gracilisabb bal oldali a. vertebralis (nyíl)

$\mathrm{MR}=$ mágneses rezonancia 
veti fel, amely a Willis-körön keresztül mindkét oldalon okozhatott elváltozásokat. Az ultrahangvizsgálat során észlelt bal oldali a. vertebralis occlusio, mely egyik angiográfiás képen sem volt kimutatható, 'bow hunter' szindróma fennállására utalhat. Az angiográfiás képek már nem mutattak artériás elzáródást, ami az antikoaguláns terápia hatásosságát jelezte. A beteg ápolása során a bal oldali facialis paresis tüneteiben mérsékelt javulást tudtak elérni. Gyermekneurológiai javaslatra rehabilitációs kezelése elindult.

A rehabilitációs osztályra való első felvételekor pupillái kissé tágak, kerekek, centrálisak, egyenlőek, fényre renyhén reagálnak. Bal oldali ptosis észlelhető. Fogmutatáskor a jobb szájfél elmarad, a homlokráncolás szimmetrikus. Jobb oldali felső végtagi túlsúlyú, mérsékelt fokú hemiparesis. A vállemelés jobboldalt szintén elmarad. A jobb felső és alsó végtagok tónusa csökkent. Jobb oldalon élénkebb mélyreflexek. Jobboldalt minimális Babinski-tendencia. Verbális kontaktusba vonni nem lehet, viselkedése részben adekvát. Szemével tárgyakat nem követ.

Édesanyja elmondta, hogy fia viselkedése már pár hónappal korábban megváltozott, indulatosabbá, nehezebben kezelhetővé vált. Nehezebben tudott figyelni, sokszor hirtelen felindulásból agresszív megnyilvánulásai voltak. Ezen problémái miatt korábban gyógypedagógiai kezelése is megkezdődött. Rehabilitációja során komplex gyógytornán, gyógypedagógiai, logopédiai foglalkozásokon vett részt, helyzetértési, szituációs és kommunikációs megsegítést kapott. Mozgásképessége spontán is fokozatosan javult, ezzel párhuzamosan zavartsága is csökkent. Nyelészavara is javult, így per os etetését is el-

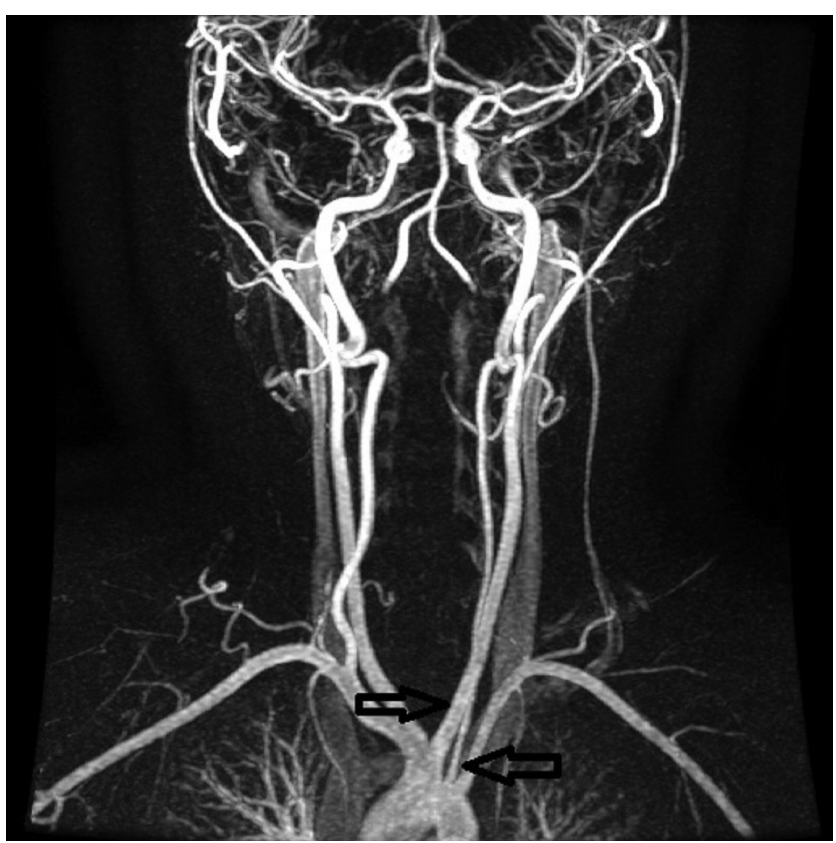

4. ábra

MR-angiográfiás felvétel. A bal oldali arteria carotis internát és arteria vertebralist érintő komplex fejlődési variáció (nyilak)

$\mathrm{MR}=$ mágneses rezonancia kezdték. Szituációértése sokat fejlődött, azonban sokszor kiabált, egy-egy szót próbált mondani, de tér- és időbeli orientációja és belátási képessége jelentősen elmaradt a korának megfelelőtől. Mobilizálását kerekes székben kezdték meg, melyet önállóan próbált hajtani.

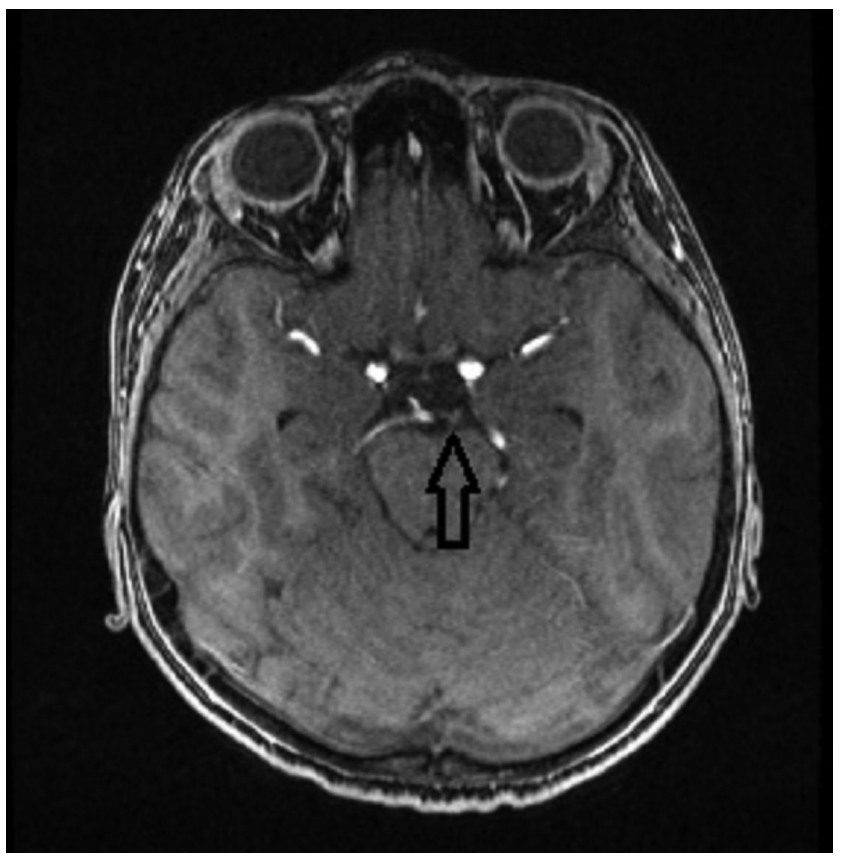

5. ábra

MR-felvétel. Az a. basilaris oszlásánál 1-2 mm-es jelkiesés (thrombus) a thalamo-subthalamicus artéria eredésénél a szuszceptibilitássúlyozott mérésen (nyíl)

$\mathrm{MR}=$ mágneses rezonancia

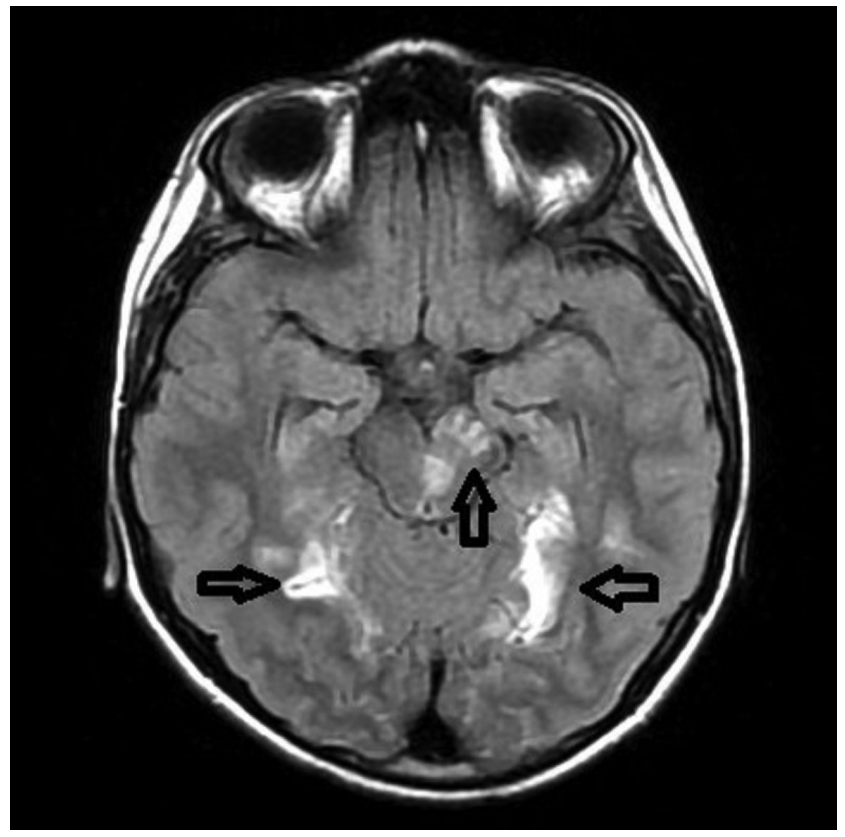

6. ábra

MR-felvétel. Ischaemiás eltérések a diffúziósúlyozott mérésen (nyilak)

$\mathrm{MR}$ = mágneses rezonancia 
Két hét adaptációs szabadságra engedték, melynek során otthonában paresise, ataxiája jelentősen javult, nagyon aktív lett, önállóan felállt, segítséggel járni kezdett. $\mathrm{Az}$ ismételt háromhetes kórházi fekvés alatt a korábban megkezdett antikoaguláns kezelést terápiás tartományban lévő anti-Xa-szint mellett folytatták. A PEG-et megszüntették. Komplex terápiája során a nagy és finom végtagmozgásaiban további javulást észleltek, ataxiája tovább csökkent, a jobb oldali dominancia azonban továbbra is észlelhető maradt. Logopédiai terápiája is folytatódott. Neuropszichológiai vizsgálat során figyelme felkelthető volt, azonban könnyen elterelődött.

Egy hónap otthoni adaptációt követően ismételten állapotfelmérés és komplex rehabilitációs kezelés céljából került osztályos felvételre. Mozgása sokat javult, azonban figyelemzavarról, hangulatingadozásokról számolt be az édesanya. A thrombophilia-panelvizsgálat során APC-rezisztencia-értékét normál felettinek találták. Viselkedészavara miatt a magatartási és koncentrációs

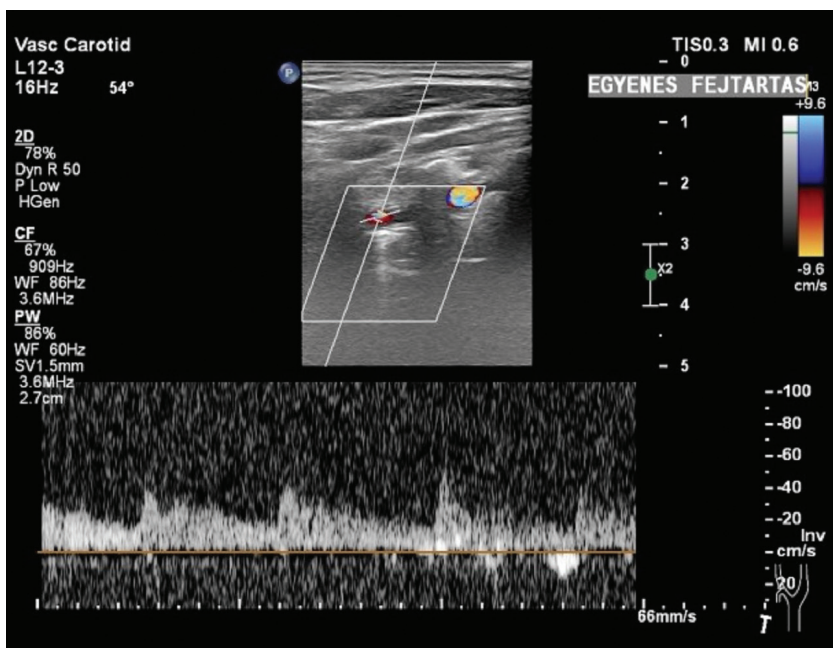

7. ábra $\quad$ Az arteria vertebralis ultrahangvizsgálata egyenes fejtartás mellett. Szabályos, trifázisos görbék

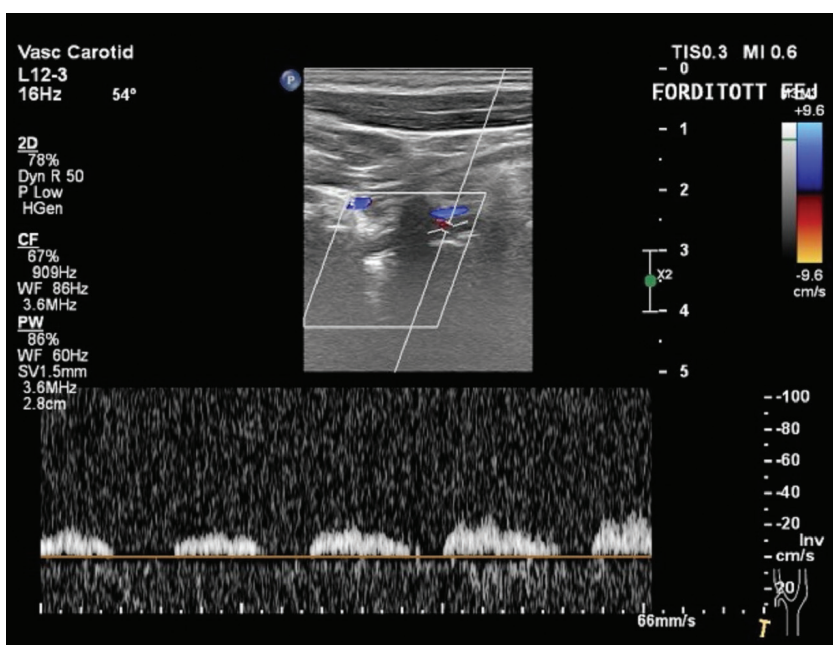

8. ábra

$\mathrm{Az}$ arteria vertebralis ultrahangvizsgálata teljesen jobbra fordított fejtartás mellett. Bifázisos görbék, az áramló vérvolumen mennyisége csökkent problémák kezelése vált elsődlegessé a további bevonhatóság és önállóság elérése érdekében.

A bal oldali a. vertebralisban, fekvő testhelyzetben végzett kontroll-ultrahangvizsgálat során, egyenes és körülbelül $45^{\circ}$-os jobbra fordított fejtartás mellett szabályos, trifázisos görbék észlelhetők (7. ábra). Teljesen jobbra fordított fejtartáskor azonban az áramlás bifázisossá válik, az áramló vérvolumen mennyisége csökkenést mutat (8. ábra). Az elfordított fejtartás mellett észlelt eltérések megnövekedett perifériás rezisztenciára utalnak, melynek hátterében distalis a. vertebralis kompresszió valószínűsíthető. Ez az eltérés DSA-vizsgálat elvégzésével pontosabban karakterizálható lenne, tekintettel azonban páciensünk fiatal életkorára, a vizsgálat nagy sugárterhelése és invazivitása miatt ettől eltekintettünk. A későbbiekben, a rehabilitációs kezelések befejezése után, a megkezdett konzervatív kezelés eredményességétől függően szóba jöhet az a. vertebralis dekompressziós mútétje, melynek megtervezéséhez szükséges lesz a felső nyaki csigolyák célzott morfológiai vizsgálata is.

\section{Megbeszélés}

$\mathrm{Az}$ a. vertebralis thrombosisos betegeket lehetőség szerint speciális stroke-osztályon kell kezelni. A thrombosisok terápiájában napjainkban széleskörúen alkalmazott eljárás a thrombolysis. A lokális intraarterialis thrombolysis jobb rekanalizációs eredményeket ad, mint az intravénás változat, sokan azonban mégis inkább ez utóbbit preferálják, annak kevésbé invazív jellege miatt. Azoknál a betegeknél, akiknél a készült radiológiai vizsgálatok egyértelmúen igazolják az a. vertebralis thrombosisát, és felmerül bizonyos agyterületek megmentésének lehetősége, a lehetó leghamarabb meg kell fontolni a thrombectomiát, lehetőség szerint intravénás thrombolysissel kombinálva [11].

Extrém esetekben és nagy vascularis sebészeti tapasztalattal rendelkező intézetekben szóba jöhet még mútéti anasztomózis kialakítása is az a. vertebralis és az a. carotis externa között. Thrombocytaaggregáció-gátló szerek (például acetilszalicilsav), valamint antikoaguláció beállítása mindenképpen javasolt [12].

A 'bow hunter' szindrómához társuló szúkü̈letes elváltozások kezelési tervét mindig egyedileg kell meghatározni a kompresszió mechanizmusától és a tünetektől függően. Szóba jöhet konzervatív kezelésként a nyaki gallér viselése, a szélsőséges nyaki mozdulatok kerülése a korábban már említett véralvadásgátló kezelés mellett [13]. Az a. vertebralis dekompressziója érdekében a processus transversus eltávolításával nyithatjuk meg a foramen transversariumot, ha lehetséges a discoligamentalis szövetek eltávolításával együtt. Ugyancsak ajánlott az artériát körülvevő rostos adventitia reszekálása. A dekompresszió szükség esetén kiegészíthető a CI-CII. szegmens hátulsó stabilizálásával is [14].

A hasonló szúkületes elváltozások kezelésére ma már elérhetők az endovascularis technikák is. Az a. vertebralis 
képalkotókkal való megjelenítésére és a beavatkozások elvégzésére a nem invazív vizsgálati módszerek és az angioplasztika közelmúltbeli fejlődése új lehetőségeket nyitott [15].

$\mathrm{Az}$ a. vertebralis elzáródásának prognózisa nagyban függ a vérellátásból kiesett agyterületek mértékétől és a beavatkozások időzítésétől, ezen kórkép mortalitása azonban igen magas. A betegek 2-5\%-ában beszélhetünk csak teljes neurológiai felépülésről rekanalizációs vagy reperfúziós beavatkozások elvégzése nélkül. A specifikus orvosi kezelések és beavatkozások eredményeinek értékelésére az etiológia teljes körü tisztázása szükséges, mert az a. vertebralis szúkületének sztentelésével történő endovascularis beavatkozás potenciálisan igen ígéretes kezelési lehetőség [16].

\section{Következtetés}

Esetünkben az elvégzett vizsgálatok alapján a kóroki szerepet az a. vertebralis lefutási fejlődési rendellenességének és a hematológiai eltérés együttesének tulajdonítjuk. $\mathrm{Az}$ édesanya által észlelt, már hónapokkal korábban jelentkező viselkedés- és figyelemromlás pedig átmeneti ischaemiás periódusok jelei lehettek. Az invazív beavatkozások az időablak túllépése miatt nem jöhettek szóba, így az antikoaguláns terápia beállítása mellett nagy hangsúlyt fektettünk a megfelelő rehabilitációs program felépítésére, melynek hatására betegünk állapotában nagymértékű javulás következhetett be. Hasonló esetekben kiemelkedő fontossággal bír a pontos és időben felállított diagnózis modern radiológiai módszerekkel, majd a beteg mielőbbi magas felkészültségű, speciális centrumba való juttatása.

Anyagi támogatás: A közlemény megírása, illetve a kapcsolódó kutatómunka anyagi támogatásban nem részesült.

Szerzői munkamegosztás: V. A. a téma irodalmazását, a klinikai anyag feldolgozását és a kézirat megszövegezését végezte. L. I. a klinikum feldolgozásában múködött közre. B. Á. M. a képalkotó vizsgálatok anyagainak értékelésében és megszerkesztésében segédkezett. Sz. Gy.-re a szakmai ellenőrzés feladata hárult. A cikk végleges változatát valamennyi szerző elolvasta és jóváhagyta.

Érdekeltségek: A szerzőknek nincsenek érdekeltségeik.

\section{Köszönetnyilvánítás}

Az alábbi kollégáknak köszönjük a beteg kezelésében való részvételt és a vizsgálati anyagok rendelkezésünkre bocsátását: Csobán Ágnes $d r$. (Magyarországi Református Egyház Bethesda Gyermekkórháza,
Súlyos Központi Idegrendszeri és Égéssérültek Rehabilitációja, Buda pest); Halics Éva dr. (Békés Megyei Központi Kórház, Pándy Kálmán Tagkórház, Gyermekgyógyászati Osztály, Gyula); Kerekes Fanni dr. (Szent-Györgyi Albert Klinikai Központ, Radiológiai Klinika, Szeged); Kövesdi József dr. (Békés Megyei Központi Kórház, Pándy Kálmán Tagkórház, Gyermek Intenzív Ellátás Osztály, Gyula); Pál Péter dr. (SzentGyörgyi Albert Klinikai Központ, Gyermekgyógyászati Klinika, Intenzív Osztály, Szeged); Török Enikő dr. (Békés Megyei Központi Kórház, Pándy Kálmán Tagkórház, Radiológiai Osztály, Gyula).

\section{Irodalom}

[1] Schulz UG, Fischer U. Posterior circulation cerebrovascular syndromes: diagnosis and management. J Neurol Neurosurg Psychiatry 2017; 88: 45-53.

[2] Chikkannaiah M, Lo WD. Childhood basilar artery occlusion: a report of 5 cases and review of the literature. J Child Neurol. 2014; 29: 633-645.

[3] Tajti Zs, Pásztor P, Bognár Á, et al. Think about it! Childhood ischemic stroke in two cases. [Gondolj rá! Gyermekkori ischaemiás stroke két eset kapcsán.] Gyermekgyógyászat 2018; 69: 163-169. [Hungarian]

[4] Celkan T, Dikme G. Thrombosis in children: which test to whom, when and how much necessary? Turk Pediatr Ars. 2018; 53: 1-9.

[5] Venkateshwar V, Raman TR, Bhalla M, et al. Vertebral artery ischaemic stroke in a child. Med J Armed Forces India 2000; 56: $155-157$

[6] Fraser AR, Zimbler SM. Hindbrain stroke in children caused by extracranial vertebral artery trauma. Stroke 1975; 6: 153-159.

[7] Greiner HM, Abruzzo TA, Kabbouche M, et al. Rotational vertebral artery occlusion in a child with multiple strokes: a casebased update. Childs Nerv Syst. 2010; 26: 1669-1674.

[8] Végh I, Harmat K, Gerlinger I. Cervical vertigo - reality or fiction? [Cervicalis vertigo - létező kórkép vagy fikció?] Orv Hetil. 2019; 160: 967-972. [Hungarian]

[9] Kroll MH, Michaelis LC, Verstovsek S. Mechanisms of thrombogenesis in polycythemia vera. Blood Rev. 2015; 29: 215-221.

[10] Tatsumi T, Shenkin HA. Occlusion of the vertebral artery. J Neurol Neurosurg Psychiatry 1965; 28: 235-240.

[11] Schoen JC, Boysen MM, Warren CR, et al. Vertebrobasilar artery occlusion. West J Emerg Med. 2011; 12: 233-239.

[12] Cloud GC, Markus HS. Diagnosis and management of vertebral artery stenosis. Q J Med. 2003; 96: 27-54.

[13] Golomb MR, Ducis KA, Martinez ML. Bow hunter's syndrome in children: a review of the literature and presentation of a new case in a 12-year-old girl. J Child Neurol. 2020; 35: 767-772.

[14] Jost GF, Dailey AT. Bow hunter's syndrome revisited: 2 new cases and literature review of 124 cases. Neurosurg Focus 2015; 38: E7.

[15] Mileva NB, Vassilev DI, Serbezova I, et al. Vertebral artery stenting in a patient with bow hunter's syndrome. JACC Case Rep. 2019; 1: 73-74.

[16] Matsubara N, Miyachi S, Kojima T, et al. Acute vertebral artery origin occlusion leading to basilar artery thrombosis successfully treated by angioplasty with stenting and intracranial fibrinolysis. Neurointervention 2013; 8: 41-45.

(Viczei Alexandra dr., Gyula, Semmelweis u. 1., 5600 e-mail: viczei.alexandra@bmkk.eu)

A cikk a Creative Commons Attribution 4.0 International License (https://creativecommons.org/licenses/by/4.0/) feltételei szerint publikált Open Access közlemény, melynek szellemében a cikk bármilyen médiumban szabadon felhasználható, megosztható és újraközölhető, feltéve, hogy az eredeti szerző és a közlés helye, illetve a CC License linkje és az esetlegesen végrehajtott módosítások feltüntetésre kerülnek. (SID_1) 